\section{SEEDS}

Surrey Energy Economics

Discussion paper Series

\section{SURREY}

ENERGY

ECONOMICS

Centre

\title{
Can the North Sea Still Save Europe?
}

Carole Nakhle

October 2007

SEEDS 118

ISSN 1749-8384

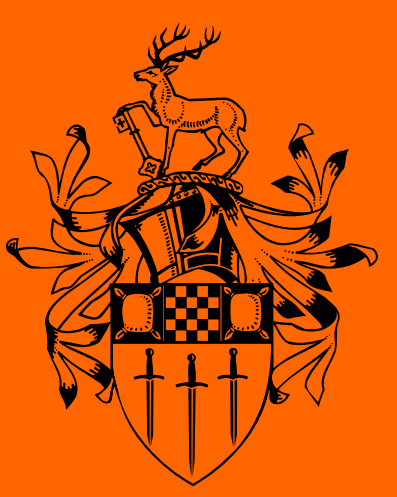

Department of Economics University of Surrey 
The Surrey Energy Economics Centre (SEEC) consists of members of the Department of Economics who work on energy economics, environmental economics and regulation. The Department of Economics has a long-standing tradition of energy economics research from its early origins under the leadership of Professor Colin Robinson. This was consolidated in 1983 when the University established SEEC, with Colin as the Director; to study the economics of energy and energy markets.

SEEC undertakes original energy economics research and since being established it has conducted research across the whole spectrum of energy economics, including the international oil market, North Sea oil \& gas, UK \& international coal, gas privatisation \& regulation, electricity privatisation \& regulation, measurement of efficiency in energy industries, energy \& development, energy demand modelling \& forecasting, and energy \& the environment. SEEC also encompasses the theoretical research on regulation previously housed in the department's Regulation \& Competition Research Group (RCPG) that existed from 1998 to 2004.

SEEC research output includes SEEDS - Surrey Energy Economic Discussion paper Series (details at www.seec.surrey.ac.uk/Research/SEEDS.htm) as well as a range of other academic papers, books and monographs. SEEC also runs workshops and conferences that bring together academics and practitioners to explore and discuss the important energy issues of the day.

SEEC also attracts a large proportion of the department's PhD students and oversees the MSc in Energy Economics \& Policy. Many students have successfully completed their MSc and/or PhD in energy economics and gone on to very interesting and rewarding careers, both in academia and the energy industry.

\title{
Enquiries:
}

\section{Director of SEEC and Editor of SEEDS:}

\author{
Lester C Hunt
}

SEEC,

Department of Economics, University of Surrey,

Guildford GU2 7XH, UK.

Tel: $\quad+44(0) 1483686956$

Fax: $\quad+44(0) 1483689548$

Email: L.Hunt@surrey.ac.uk

www.seec.surrey.ac.uk 


\title{
Surrey Energy Economics Centre (SEEC) Department of Economics University of Surrey
}

\author{
SEEDS 119
}

ISSN 1749-8384

Can the North Sea Still

SAVE EUROPE?

Carole Nakhle

October 2007

This paper may not be quoted or reproduced without permission. 


\begin{abstract}
In the 1980s and 1990s the North Sea emerged as a key non-OPEC oil producing province. Yet today overall production is declining, in both the British and Norwegian sectors and the big oil companies and investors are losing interest in what they now see as a mature province. But apparent maturity is not a bar to new prospects and new possibilities. This paper analyses not merely the still significant potential of the North Sea, but also the wider and increasingly attractive prospects offered by the opening up of the High North, the Barents Sea and part of the Arctic region - all areas of rapidly growing interest which are on Europe's doorstep. Success will depend heavily on key questions such as the world oil price trend, technological advance and the structure of fiscal regimes for oil and gas extraction. But the opportunities are there and they could be to Europe's great advantage.
\end{abstract}

Key Words: North Sea, High North, Fiscal Regime, Oil Price, Mature Oil Province 


\title{
Can the North Sea Still Save Europe? \\ Carole Nakhle
}

\author{
Surrey Energy Economics Centre (SEEC) \\ Department of Economics \\ University of Surrey \\ Guildford, GU2 7XH \\ Surrey, $U K$ \\ Email: C.Nakhle@surrey.ac.uk
}

\section{INTRODUCTION}

\subsection{Overview}

The North Sea emerged as a key, non-OPEC oil producing area in the 1980s and 1990s. Its political stability and proximity to major European consumer markets have given it a major role in world oil and natural gas markets as well as making it a reliable supplier for Europe. Yet today, Europe seems to be shifting its attention away from the North Sea and drifting into bigger dependence on oil and gas from politically less stable areas. According to the European Union (EU) Commission (2006), if present consumptions patterns continue in the EU, oil and gas imports are likely to increase significantly over the next 25 years, with the bulk of them coming not from the North Sea but from Russia, North Africa and the Middle East.

It is true that the North Sea can today be described as a mature province, in the sense that production has peaked and the remaining reserves to be exploited are smaller and/or more technically challenging than those developed in the past. But a mature province is not necessarily a dying province that is slipping into history. Other basins, such as the Gulf of Mexico, have undergone similar up-and-down-and-up life cycles. The Gulf of Mexico has become one of the hottest exploration areas in the world, just a few years after it has been declared a dead sea for exploration potential. 
There are those who seek to by-pass the issue of future reliable oil and gas supplies by arguing that the European energy future lies less with fossil fuels than with renewable sources and, in the longer term, with a renewed expansion of nuclear power. These sources will play their part, although the recent increased EU target of 20 percent of European energy from renewables by 2020 looks unrealistically ambitious, while nuclear power expansion remains fraught with political difficulties, as well as severe financial challenges. A degree of realism is therefore urgently needed. According to the International Energy Agency (2006), fossil fuels will remain the dominant source of energy up to 2030. The share of oil will drop, but oil will still be the largest single fuel in the energy mix in 2030. Applying this template to Europe in 2030 , the expectation is that 35 percent of total energy consumption will still come from oil and 27 percent from gas - the crucial difference from today's supply pattern being that 90 percent of the oil required will be met from imports and at least 80 percent of gas from imports - the bulk of this from Russia, Africa and the Middle East (EU Commission, 2006).

It is little wonder many Europeans are uneasy at this prospect and are beginning to search in different directions. In the telling words of Javier Solana, the EU's foreign affairs High Representative and spokesman, 'we should go and look for more oil and gas'... and the world, more precisely Europe, 'should look for a reliable supplier'. At least for Europe it could be right on its doorstep. Or in the blunter words of the Norwegian Foreign Minister 'Europe should begin to look North'.

\subsection{Objective}

It is against such a background of anxiety and fresh thinking that this paper seeks to analyse not merely the remaining potential of the North Sea (the UK and Norwegian shelves) but also the wider regional potential offered by the opening up of the High North and the Barents Sea 
- areas which are indeed 'on Europe's doorstep', or at least extensively linked by an expanding pipeline system, and with a potential capacity to keep Western Europe well and reliably supplied for many years ahead.

In particular, the paper seeks to show that the North Sea's role as a major oil and gas source is very far from ending, that both the UK and Norway have a major further role to play in oil and gas supplies, but that the success of this will depend heavily on key matters such as the future world oil price trend, the pace of technological advance and the design of fiscal regimes for oil and gas extraction. It is certainly the case that UK North Sea oil and gas deposits have been depleted very fast in recent years. But in the North Sea as a whole, including the Norwegian sector, lot of discoveries are awaiting development. One third of its oil and gas reserves, as currently identified, have not yet been produced. Substantial opportunities remain to be accessed. The limitations are profitability (largely determined by oil price and fiscal regimes) and technology, rather than resources.

In sum, the North Sea, as we know it today, can either face a rapid decline, hence exposing Europe to an increasing dependence on oil and imports, or production can be sustained for a longer period of time, hence extending the benefits to consumers, companies and government alike. At the same time, if Europe is to face its energy future in a spirit of hard realism then the search must extend beyond and above the North Sea, to other regions, namely the Barents Sea and the high Arctic north. Together with the UK and Norwegian Continental Shelves, already largely explored, these areas, admittedly more distant and more difficult, are nevertheless the ones which could substantially change the geopolitics of both oil and even more of gas - at least from the European perspective. 


\subsection{Methodology and Structure}

The analysis which follows is designed to solidify and give substance to some of the inevitable speculative assessments of oil and gas potential in these regions. It is largely based on official forecasts and estimates of remaining reserves. It considers the impact of various oil price scenarios on the exploration and production activities and it assesses the all-important prevailing fiscal impact on the profitability, hence attractiveness of the northern region, both the existing North Sea province and the new areas further north.

The paper falls into four parts. After this Introduction, Section 2 analyses the potential of the main players in the North Sea and the higher north regions, namely the UK and Norway. Section 3 studies the issues which arise in assessing the factors which will or could lead to an unlocking of potential reserves. These include oil price trends, fiscal regimes and technological innovation as well as pipeline availability and other infrastructure developments. To obtain the full picture account needs also to be taken of the growth of Liquid Natural Gas (LNG) facilities and transportation within the Northern European and North Sea regions. Section 4 incorporates the summary and conclusions about the entire region and its relevance for Europe's energy future. 


\section{Europe, THE NORTH SEA AND THE High NORTH}

\subsection{General: The North Sea, past, present and future.}

The Past

The discovery of oil in the North Sea came at a critical time in the history of the world oil market. In the 1970s, fundamental changes in the world oil market began to take place. Prices rose steadily from 1970 to 1973 , when the price upsurge took off which left world oil prices in mid-1977 at approximately eight times their level in 1970. At the same time, the OPEC countries, by means of participation agreements and nationalization, took control of producing operations away from the oil companies (Robinson and Morgan, 1978). Despite being a relatively high cost region for oil and gas production, its political stability and proximity to European consumers have allowed the North Sea to play a major role in world oil markets.

\section{Present}

The North Sea has been a sizable oil producer. It has emerged as a key, non-OPEC oil producing area in the 1980s and 1990s. As already noted its political stability and proximity to major European consumer markets have allowed it to play a major role in world oil and natural gas markets as well as being a reliable supplier for Europe. Norway and the UK - the North Sea's largest producers - together account for 5.7 percent of global supplies. Within Europe, the two countries hold the vast majority of oil and gas resources, account for 84 percent of the continent's production, and meet over 25 percent of total oil consumption needs (Global Insight, 2007).

Today, however, oil output from those two large producers has peaked and entered a period of long term decline, driven by the maturing of many of the North Sea's major fields and a 
lack of significant new discoveries. During 2006, oil production in the North Sea reached 4.4 million barrels per day (bbl/d), down from 4.7 million bbl/d in 2005. By 2007, production levels were about one-quarter lower than that in 1999 (EIA, 2007). In the case of natural gas, the North Sea is also seen as a mature region. Only Norway has seen an increase in natural gas production in recent years, while the UK became a net gas importer in 2004. But the North Sea's importance as a key supplier of natural gas will continue, given the significant increase in natural gas consumption in Europe in the near future. In these circumstances the North Sea region is bound to remain an important source of natural gas for Europe, second only to Russia in total supply to the EU (EIA, 2007).

\section{Future}

The maturity of the North Sea oil by no means implies that the oil and gas era has ended in this province. Other basins, such as the Gulf of Mexico, have undergone similar evolutions and seen activity actually increase (Ruairidh, 2003). Also, it should not be forgotten in concentrating on the more northerly scene that North Sea potential lies not only in the UK and Norway. The Denmark and the Netherlands are also important oil and more importantly gas suppliers to Europe (especially given the various infrastructure and pipelines that link them to the rest of the North Sea) although Denmark's situation is different to other North Sea countries due to its predominantly tight chalk reservoirs with lower production but later peaking and slower decline (Wurtzen, 2007). The Netherlands, which has been an established gas source for northern Europe for several decades, nevertheless still possesses a significant number of marginal fields awaiting development. According to McKellar (2006), the Dutch North Sea is still an interesting core region and integral part of any 'gas in Europe' strategy. A closer examination of the North Sea situation in relation to the UK now follows. 


\subsection{The UK Continental Shelf}

The UK holds 30 per cent of total proven oil reserves in the North Sea. It remains a larger gas producer than Norway but now (2007) second to Norway in oil production at 1.5 million $\mathrm{bbl} / \mathrm{d}$, or 34 per cent of both sectors, the British and the Norwegian, combined.

Nonetheless, the UK ranks high in the global league of oil and gas producers. In 2004, production from the UK Continental shelf (UKCS) accounted for more oil and gas than Venezuela, Nigeria, Indonesia or Kuwait (Crawford, 2006); producing 1.3bnbbl of oil and gas in total, sufficient to provide over 80 percent of the nation's total energy needs (Oil \& Gas UK, 2006). The UK remains a major non-OPEC oil producer. In 2006, it had 4.0 billion barrels (bnbbl) of proven crude oil reserves, by far the largest of any EU member country (EIA, 2007). In the same year (2006), oil production reached 588 million bbl, providing respectively 96 percent of the nation's oil and gas consumption.

The UK has been a net exporter of crude oil since 1981. Its largest export destinations in 2004 were the United States (28 percent), and other European countries (52 percent), chiefly the Netherlands, Germany and France (EIA, 2007).

Actual oil production in the UK sector peaked in 1999 at 2.9 million bbl/d, and has been declining since. The two main reasons given for this decline are, firstly, the overall maturity of the UKCS oil fields and, secondly, the declining size of fields, both in terms of new discoveries and developments. Additionally, increasing unit extraction costs, in what is acknowledged to be one of the highest cost basins in the world, are damaging project economics and basin competitiveness. A shift of basin production to more remote and inhospitable areas of the UKCS is also a factor. Crude oil exports have followed a similar 
path to production, although they initially levelled off between 1999 and 2000 before slowly declining. Crude oil imports have risen steadily to narrow substantially the gap with exports although the UK still just remains a net exporter of crude (DTI, 2005).

In terms of natural gas, the UK is the fourth-largest producer of natural gas in the world. But in 2004, the country became a net importer of natural gas for the first time since 1996. In 2006, gas production reached 85 billion cubic meters $(\mathrm{bcm})$ providing 92 percent of the nation's gas needs (Oil \& Gas UK, 2006).

Since 1975 , the UKCS has undergone major changes. One fact that clearly emerges is the decline in the average size of fields during the 1990s, compared with the early development of the North Sea. Discoveries now average at 20-30 million barrels of oil equivalent (mmboe). This is 50 to 100 times smaller than the fields on which the North Sea was built (Oil \& Gas UK, 2006).

A minority of fields account for the majority of aggregate reserves. The largest five fields account for 37 percent, the largest 10 for 52 percent and the largest 20 for 71 percent of the total reserves (Watkins, 2000). However, 29 of the UK major UK fields peaked prior to 1994 (DTI, 2005). By 2000, they had total oil production declines of more than 50 percent from their maximum production levels (Blanchard, 2000).

To counteract the rapid decline of mature fields, new but smaller fields are being brought online at an increasing rate. From 1985 to 2006, the number of producing fields on the UKCS has increased three-fold. Although it took 25 years for the first 100 fields to be brought online it took only six years to bring the second 100 fields on-line (Blanchard, 2000). As might 
be expected, however, the fields found during subsequent periods have become progressively smaller, with an average discovery size of 25 to $30 \mathrm{mmbbl}$ of oil equivalent. That is modest compared to the larger UK fields, like Forties and Brent, with an average size above 2,400mmboe (Sem and Ellerman, 1997). Furthermore, many of the new smaller fields have lifetimes of 10 years or less. In an extreme example, Dauntless field was brought on-line in August 1997 and was terminated in April 1999 (Blanchard, 2000).

In a survey carried out by Nakhle (2005), 40 percent of respondents agreed that despite the maturity of the UKCS, the UK North Sea era has not ended yet. Similarly, according to a study carried out by UKOOA and WoodMackenzie in 2004, there are still substantial opportunities to be accessed if the UK remains internationally competitive and can sustain current investment. If successful the UK could still be producing the equivalent of 65 percent of its total oil requirements in 2020 and delay decommissioning by 10-15 years, making a major contribution to the UK's security of energy supply. In stark contrast, if the UK becomes less attractive to new investment, then the UKCS will only provide the equivalent of 15 percent of total UK oil demand by 2020 (Oil \& Gas UK, 2006). Consequently, the UKCS can either face a rapid decline, hence exposing the UK to an increasing dependence on oil imports, or production can be sustained for a longer period of time, hence extending the benefits to various stakeholders. The same scenarios apply to gas. The UK will remain a significant producer of gas for years to come. According to Oil \& Gas UK (2006), current production plans are only expected to deliver about 10 percent of UK gas demand in 2020 , but, with sustained investment, UKCS production could still meet around 25 percent of such demand ${ }^{1}$.

\footnotetext{
${ }^{1}$ Section 3 discusses the factors that can affect the future of the UKCS.
} 


\subsection{The Norwegian Continental Shelf of the North Sea}

The claim has been made that Norway is, or could become, Europe's Saudi Arabia (Faris, 2007). Norway ranks as the world's fifth largest oil exporter and the tenth largest oil producer. The country is a significant oil exporter; because it consumes a relatively small amount of oil each year. Thus it is able to export the vast majority of its oil production. In 2005, Norway was the third largest gas exporter and the seventh largest gas producer in the world. In 2005 Norway exported 2.2 million bbl/d of oil, supplying 17 per cent of the EU total gas demand and 13 per cent of its oil demand (The Norwegian Petroleum Directorate, 2007).

Despite more than 30 years of activity, the Norwegian side of the North Sea still has significant oil and gas deposits to develop. Norway contains the bulk of oil reserves in the North Sea (57 per cent). It is also the largest producer of oil with 2.5 million bbl/d or about 57 per cent. Together with the Netherlands, Norway accounts for over three-fourths of gas reserves (EIA, 2007). Most Norwegian gas is sold through long term deals to Britain and other European countries.

When the North Sea was opened up for petroleum activity, the most promising areas were explored first. This led to world class discoveries which were then put into production. These fields have been and still are of great significance for the development of the Norwegian Continental Shelf (NCS). The large fields have contributed to the establishment of infrastructure that subsequent fields have been able tie into. Although Norwegian oil production in the North Sea started to decline in 2000, there is still a considerable potential for value creation in these areas if the recovery rate in producing fields is increased, operations streamlined and resources near existing infrastructure are explored. 
According to the Ministry of Petroleum and Energy (2006), Norway has a potential for maintaining profitable oil production from the North Sea for another 50 years and its gas production for another 100 years. Since Norway exports more than 90 per cent of its oil production this makes it a continuing and significant factor on the global energy supply scene.

Oil production from the NCS of the North Sea peaked at $3.4 \mathrm{mbbl} / \mathrm{d}$ in 2001 (Global Insight, 2007). But while oil production has started its inevitable decline, gas production is on the increase. By 2007, Norway's annual gas production reached $85 \mathrm{bcm}$. According to foreign ministry forecasts from Oslo, early in the next decade (2010), Norway's gas exports will have risen by 50 per cent to $130 \mathrm{bcm}$. This means that exports from Norway will by then account for nearly a third of natural gas consumption in France, Germany and the UK.

A conservative estimate indicates that so far Norway has produced one third of its proven petroleum resources (Foreign Ministry, 2007). This is good news for customers in the West, since energy demand is increasing and a politically stable supply network is of the utmost importance (Faris, 2007). For over 30 years, oil from the NCS has found its way to US markets. Now the time has come for natural gas.

\subsection{Beyond the North Sea; a New Sea of Opportunities?}

Already a new source pattern is opening out. Norwegian oil and gas are not coming from the North Sea only. Norway's oil and gas potential as a whole comes not only from the North Sea, but also from the Norwegian and the Barents Seas. 
In the 'established' North Sea itself, about 57 per cent of proven oil and gas reserves have been produced. The remaining reserves are divided 34 per cent oil and 66 per cent gas. But further north in the Norwegian Sea only about 25 per cent of oil and gas reserves have been produced. The remaining reserves are 35 per cent oil and 65 per cent gas (The Norwegian Petroleum Directorate, 2007). One third of Norway's remaining petroleum reserves are estimated to be in the Barents Sea (Foreign Minister, 2007). Thus, the Norwegian hydrocarbon energy story, which started in the North Sea proper, is already moving north into the Norwegian Sea, into the High North, and stretching beyond the Arctic Circle into the Barents Sea. Another world of energy beckons.

On April, 24, 2006, Norwegian Foreign Minister Jonas Gahr Støre published, in the Swedish newspaper Svenska Dagbladet, a highly significant letter article entitled "A sea of opportunities". In that letter Store urged the EU to look north for energy. Increased extraction of oil and natural gas from the Barents Sea could provide Europe with its much needed energy, the minister said. The letter sketched a European energy scenario focusing on the icepacked northern parts of the planet. The traditional conception of the world, the Minister pointed out, classically defined with Europe in the middle, and America and Asia on the outer wings was only one way of looking at the map. If we instead placed the Nordic areas in the centre, the perspective changed dramatically. The Arctic Ocean then became a mutual sea between Europe, Russia and North America.

\subsection{The High North}

The High North covers the areas of the Arctic adjacent to Norway, the northernmost parts of Scandinavia and Russia, and the ocean areas to the north of these countries. Estimates by the 
US Geological Survey indicate that the High North holds a quarter of the world's undiscovered oil and gas resources.

The Barents Sea is a part of the Arctic Ocean located north of Norway and Russia. It is bordered by the shelf edge towards the Norwegian Sea in the west, the island of Svalbard (Norway) in the northwest, and the islands of Franz Josef land and Novaya Zemlya (Russia) in the northeast and east.

These are without doubt difficult areas with heavy extraction costs. No-one questions that. But what now places them firmly on the energy agenda is the ever-rising security of supply anxieties across the world. What four years ago looked like remote geologist's speculation, well beyond the range of commercial consideration now begins to appear quite different. Top US, European Union, Russian and Norwegian officials now agree that the Barents Sea has great potential to be a new world-class petroleum province and a key energy provider for Europe and the US (Howell and Nakhle, 2007).

To date there has been little exploration activity in the Barents Sea to reflect this new interest and the region remains by far the least explored part of the NCS. Two commercial discoveries have been made so far - the Snøhvit gas field and the Goliat oil field. These encouraging discoveries have confirmed that there are more resources to be found. It is not surprising, therefore, that when added to the high oil price and a background of Norwegian political stability the overall conditions and prospects are prompting increasingly hard thinking about new investments and plans in the area. 
Statoil's Snøhvit (Snow White) field is the first field development in Norway using natural gas liquefaction technology and the northernmost LNG development in the world. Snøhvit is significant not only for its reserves but also for the fact that it is Europe's first LNG export terminal. The project was expected to begin operations in 2005 , but cost overruns have pushed back the start-up date until 2007. The development of Snøhvit provides a basis for further field developments in the Norwegian part of the Barents Sea based on LNG. In April 2006, for the first time, gas from the "Snohvit" gas reservoirs in the Barents Sea has been brought to the land surface. The gas, which is located 2500 meters under the sea floor was brought to the surface without emissions to the surrounding. From deep-sea wells in the frosty Barents Sea, gas would flow to shore through an underwater pipeline. There are no platforms or ships on the surface. Snohvit will provide a significant contribution to overall Norwegian gas production. At the same time, the fields entail establishment of new infrastructure that can serve future field developments.

Meanwhile, as the world's largest consumer of energy, the U.S. is increasingly looking to diversify its imports away from politically unstable areas such as the Middle East. By autumn 2007, shipments of LNG from the Snohvit field in the Barents Sea will sail to the Cove Point terminal in Maryland - creating yet another bond between the US and Norway across the Atlantic. The Barents Sea could offer the U.S. a stable alternative supply of both crude and liquefied natural gas. The EU should surely be looking the same way. 


\section{The Crucial Factors Affecting North Sea and Higher North INVESTMENT}

The future of the North Sea depends on the level of investment in exploration and development activities, which in turn depends on a combination of factors. In the UKCS, for instance, continued investment has the potential almost to halve the production decline rate to the end of the decade from seven percent per annum to four percent per annum.

In examining the attractiveness of any oil or gas province, a prospective investor will take into many factors. The main ones will include:

- Basin prospectivity (the chance of finding oil or gas)

- Volumetric potential (how large are the discoveries)

- Basin cost structure (overall finding, development and operating costs per billion of oil equivalent)

- Access to infrastructure and opportunities

- The fiscal regime - its evolution, complexity and stability

It is the balance of the above factors which will enable the investor to assess a basin's or province's competitiveness (Nakhle, 2007).

Applying this template to the 'established' North Sea, volumetric potential is unlikely to feature significantly. This is because there is an insufficient resource base to attract larger oil company investment, particularly when other international opportunities are in keen competition for funds (Sassoon, 2003). Exploration and developments costs are also high. The North Sea may not provide the volume that satisfies larger investors, but it can provide value. The factors that will determine its future therefore lie much more in the area of oil price, technology and the fiscal regime. 


\subsection{Crude Oil Prices}

High oil prices have clearly helped in maintaining investment, as smaller fields that were previously considered uneconomic become more commercial. The increase in oil prices since 2004 has been one of the major factors that encouraged greater interest in the North Sea. By 2007, there were 143 active companies on the UKCS compared to 77 in 2001 , with the $24^{\text {th }}$ license round seeing 17 new entrants (Westwood, 2007). Similarly, interest in the Norwegian shelf is as strong as ever. Exploration activity on the Norwegian shelf actually increased in 2006 after several years of decline. The considerable interest shown in February 2007 licensing round, confirms just how attractive the exploration acreage on the Norwegian shelf continues to be. Never before have so many production licenses been awarded on the Norwegian shelf. The licensing rounds in recent years also indicate that more and more new players are entering the Norwegian shelf (Norwegian Minister of Petroleum and Energy, 2007).

But, if recent years have been dominated by rising oil and gas prices, they have also been dominated by rising costs given the decline in production as well as the global competition for rigs and human resources which pushed the costs upwards. There are too many companies chasing too few dollars and too few rigs to meet demand (Westwood, 2007). As production declines it becomes increasingly challenging to sustain the competitiveness of a basin of this character. According to Oil \& Gas UK (2007), if the UK is to make the most of its indigenous hydrocarbon resources and recover about 21 billion of barrels of oil equivalent (boe), it will be necessary for companies to invest $£ 100$ s of billions in technically and commercially risky opportunities in a mature, high cost oil and gas province. 
Paradoxically, high oil and gas prices both contributed to and constrained activity in the oil and gas sector in 2005. While they had the effect of making a greater volume of reserves economically attractive to recover, they also put pressure on resources and increased capital development and exploration and appraisal costs, reflecting a global trend (Oil \& Gas UK, 2006). As such, higher prices should be seen as a compensation for rising costs instead of an incentive for the government to raise taxes (Nakhle, 2007). Martin (1997) argues that higher oil prices if, considered alone, are not a sufficient variable to explain increase in production; technological and fiscal changes are key factors.

\subsection{The March of Technology}

Technological change on oil and gas exploration play a significant role in the offshore industry increasing reserves and lowering cost (Managi et al, 2005).

The Norwegian companies have impressively developed their competences and technological knowledge on the NCS over the last 35 years. Today, technology developed on the NCS is utilized by the international oil and gas industry all over the world. Norway is the world's biggest operator of submarine gas pipelines. The giant concrete platforms of the 1970s and 1980s were followed by floating production and sub-sea systems. Now comes the development of seabed separation and extended well stream transfer to onshore handling plants. The Hydro operated Ormen Lange field and the Statoil operated Snøhvit field are good examples of world class technologies developed in Norway over the last 35 years.

Technology also helps to bring costs down, to make old fields look young again and to improve recovery rate. In 1995, the average recovery rate for oil in producing fields in the North Sea was approximately 40 per cent. In 2007, it became 46 per cent (NPD, 2007). 
Improved technology makes it possible to achieve profitable development of more resources. Technology also extends the lifetime of fields; it makes operations profitable even when production is low.

\subsection{The All-important Fiscal Context.}

Both oil prices and technology go beyond government's control, unlike the fiscal regime. In countries where oil production has started to decline, fiscal regimes can be tuned to compensate for the decline in production by encouraging existing and new companies to sustain production and develop the remaining less profitable fields (Nakhle, 2007).

There are close similarities in the structure of the fiscal regimes that apply in both the UK and Norway. Both countries apply a concessionary regime, where oil companies take title to produced oil at the wellhead and then pay the appropriate royalties and $\operatorname{taxes}^{2}$ (Blinn et al, 1986). The UK and Norwegian petroleum fiscal regimes include Royalty, special petroleum tax and corporate income tax. Royalty is based on the value of oil and gas extracted but it was abolished in both countries - in 1986 in Norway, and in 2002 in the $\mathrm{UK}^{3}$. Royalty was abolished to encourage investment in oil and gas activity in both shelves. Since Royalty applies on gross revenues, it is a regressive tax that can render profitable projects unattractive on a post-tax basis, in addition to its up-front effect because it is imposed concurrent with the commencement of production.

Given the perceived special characteristics of the oil sector, mainly the availability of economic rent, a special tax instrument applies to capture the windfall profits. The UK

\footnotetext{
${ }^{2}$ The other main type of petroleum fiscal regime is the contractual regime where the government retains ownership of production while the international oil company operates at its own risk and expense under the control of the government.

${ }^{3}$ In the UK, Royalty was firstly abolished on fields that received development consent before 1983, then abolished on all fields in 2002 (Nakhle, 2006)
} 
applies Petroleum Revenue Tax (PRT) at 50 percent on fields that received development consent before 1993, and Norway applies Special Petroleum Tax (SPT) also at 50 percent. The corporate income tax that applies in both countries is the general tax that applies to all companies operating in the two countries respectively. The Norwegian Corporate Income tax (CIT) applies at a rate of 28 percent. In the UK, the Corporation Tax (CT) applies at a rate of 30 percent, but in 2002 the UK Government introduced a Supplementary charge that applies at a rate of 10 percent on the same base as CT, and then in 2005 the UK Government doubled the charge to 20 percent, hence overall the corporate income tax applies at a rate of 50 percent in the UK. But unlike PRT in the UK, the SPT is not deductible for CIT purposes, rendering the total tax take more significant compared with the UK. The effective marginal tax rate in Norway is 78 percent. In the UK, the effective marginal tax rates ranges between 50 percent and 75 percent, as two structures applies - the first that applies to fields that received development consent after 1993, and it is based on 50 percent CT, the second applies to fields that received development consent before 1993: in addition of 50 percent CT, a 50 percent PRT applies.

The Norwegian regime is often compared with the UK oil tax regime ${ }^{4}$. Divergences have clearly emerged. The Norwegian regime is significantly simpler as one structure applies to all fields while in the UK two structures apply depending on the date of development consent of fields. The Norwegian petroleum fiscal regime is also much more stable. Since the establishment of the UKCS tax system in 1975, the regime has been repeatedly reviewed and many amendments applied. Rowland and Hann (1987) argue that no other sector in the UK economy has been subject to such fiscal instability. The missing element in the UK tax profile has been stability. Stability is an intangible yet crucial attribute of any fiscal regime. It

\footnotetext{
${ }^{4}$ Robinson \& Morgan (1978), Robinson \& Rowland (1978), Brent (1991), Quinlan (1998)
} 
directly affects the confidence of investors in government policy, and this is particularly so in the case of petroleum extraction activity, where long-term projects are the norm.

High level of government take is bound to cause problems where high-risk exploration and high-cost development are the norms, or in the case of those provinces with remaining modest petroleum potential, as is now the position in the North Sea. In the UK, the increase in taxation in 2005 reduced oil and gas activity attractiveness in the UK by 16 per cent (Oil \& Gas UK, 2006). The cost of producing oil can overwhelm any price incentive. Large price incentives are needed to increase production while the costs of production are rising. The rapidly rising costs of operating in the North Sea, the global shortage of rigs and resources and high and unstable tax regimes all have the potential to frustrate companies' plans and can lead to a failure to maximize the production of oil and gas. It is highly unwise for the authorities to assume that the North Sea will remain a preferred location for investment even at current high oil and gas prices (Oil \& Gas UK, 2006).

Controversy will always prevail when it comes to taxation, given the competing objectives of the two main players: governments normally seek to generate high levels of take from oil related activity while oil companies want to ensure an acceptable and sufficient level of profitability in their operations. But higher tax takes do not necessarily mean higher revenues. When the UK Government introduced the Supplementary Charge, they expected to generate an additional £2billion (bn) from oil activity in 2006-2007 as a result of the increase in tax. However, six months after the increase in tax, estimates were revised and the UK Government wrote off three-quarters of the $£ 2$ bn originally expected revenues, in the light of the decreasing North Sea production (Giles and Hoyos, 2006). Then, in the space of further 
six months following the March 2006 Budget the UK Government further reduced the yield expectations from the North Sea by $£ 2.8$ bn in the tax years 2007-8 (HM Treasury, 2006).

In the light of the conditions in the North Sea, taxation, instead of deterring investment and production and leading indirectly to loss of fiscal revenues, could be used to the opposite effect, namely as an instrument to compensate for the decreasing attractiveness of the province, with respect to prospectivity and costs. By getting their priorities right, governments can encourage activity while sustaining a stable of flow of revenue.

\section{SUMMARY AND CONCLUSION}

The analysis carried out in this paper on both the established North Sea province and the new potential opening further north confirms that the role of the entire area as a major oil and gas supplier is far from ending. Indeed, it could be only just beginning. As the potential unfolds, Europe's energy prospects could be significantly improved, with sharply reduced reliance on imports from politically unreliable sources.

It is true that UK North Sea oil and gas deposits have been depleted very fast in recent years but in the North Sea as a whole, including the Norwegian sector, further considerable discoveries are awaiting development. About one third of its oil and gas reserves, as currently identified, have not yet been produced.

However, these prospects, while real and immediate, may be less significant than the truly large potential already opening out further North. It is the reserves estimated to exist in the 
Barents Sea region and under the Arctic ice which could both transform and stabilize the future oil and gas supply pattern for Europe and dramatically reduce current anxieties.

Many powerful reasons exist for a highly positive approach to these future developments, both in the North Sea (on both the UK and Norwegian Continental Shelves) and in the High North.

First, the likely continuance of a high world oil price is bound to be a significant factor. Many studies confirm that high oil prices are here to stay (Howell and Nakhle, 2007, IEA, 2007). Second, the continuing rapid development of petroleum technology is making, and will continue to make, an important contribution to increasing the activity level. It is this, alongside crude oil price prospects, that opens up the new possibilities for under-ice recovery so realistically. Third, it has been shown that significant potential remains on both sides of the established North Sea province, despite many commentaries tending to 'write-off' the North Sea's future significance for European energy needs. Finally, the existing North Sea province enjoys an increasingly integrated and effective supply chain, backed strong and extensive infrastructure (Webb, 2007). In particular, the natural gas production platforms in the North Sea are well integrated by a network of domestic and international pipelines. This network facilitates the movement of natural gas both within the North Sea basin and exports to continental Europe.

To the question 'Can the North Sea Save Europe' the answer is therefore 'Yes, but'. Yes, the potential, both that remaining in the established North Sea province and that now plainly opening up further north, is there to transform Europe's energy supply situation and meet the 
unavoidable expansion of demand for hydrocarbons, whatever the progress in low carbon alternatives.

However the obstacles to this better future remain. Lack of determination, lack of vision, both commercial and political, lack of policy agility, poor fiscal policies and sterile geo-political perspectives can leave these new possibilities stillborn. Europe's leaders and policy-makers, and their advisers, now have the responsibility to ensure that does not happen. 


\section{REFERENCES}

Bevanger, L. (2004) "Norway Prepares for Dry North Sea”, BBC News 24, 14 April.

Blinn, K., Duval, C., Leuch., H. (1986) "International Petroleum Exploration \& Exploitation Agreements- Legal, Economic and Policy Aspects", Barrows Company Inc.

Brent, N., (1991) "The State Offshore: Petroleum, Politics, and State Intervention on the British and Norwegian Continental Shelves", Praeger Publishers, NY.

Crawford, R. (2006) “Gordon’s own goal?” Parliamentary Brief, vol. 10, no. 5, pp. 21-23.

Department of Trade and Industry (DTI) (2005) “Digest of United Kingdom Energy Statistics”, DTI.

Energy Information Agency (EIA) (2007) "North Sea: Country Analysis Brief", http://www.eia.doe.gov

EC Commission Press Release (2006) "An External Policy to Serve Europe Energy Interests", Paper from Commission/SG/HR for the European Council.

EU Commission (2006) "Energy for a Changing World", EU Energy and Climate Policies adopted by the European Commission.

ExxonMobil (2007) “The Outlook for Energy - a View to 2030”.

Faris, S. (2007) "All Eyes North: why Norway is keeping watch on its reserves, resources and Russia", Monocle, April, Issue 2, pp. 25-39.

Giles, C., Hoyos, C. (2006) “North Sea tax revenue cut by £1.5bn”, Financial Times, 25 March.

Global Insight (2007) "United Kingdom - Norway: The End of an Era? The Outlook for Oil Production in the North Sea and Surrounds", June.

HM Treasury \& Customs (2006) "Regulatory impact assessment for changes to the north sea tax regime", http://www.hmrc.gov.uk/ria/ria-north-sea-regime

Howell, D., Nakhle C. (2007) “Out of the Energy Labyrinth”, I.B.Tauris, London.

International Energy Agency (IEA) (2007) "World Energy Outlook".

Managi, S., Opaluch, J., Jin, D., Grigalunas, T. (2005) "Technological change and petroleum exploration in the Gulf of Mexico", Energy Policy, vol. 33, pp. 619-632.

Martin, S. (1997) "Tax or Technology? The Revival of UK North Sea Production", Oxford Institute for Energy Studies.

McKellar, K. (2006) “Going Dutch? A Parallel Development beside the SNS”, Deloitte.

Nakhle, C. (2007) "Do high oil prices justify an increase in petroleum taxation in a mature, declining province? The case of the UKCS", Energy Policy, vol. 35, no. 8, pp.4305-4318.

Nakhle, C. (2005) "Opinions on the UK North Sea Petroleum Fiscal Regime: Preferences Revealed", International Energy Law and Taxation Review, May, Issue 5, pp.101-114.

Quinlan M. (1998) "North Sea Oil and Gas Province", Petroleum Economist, August 98

Robinson, C., Rowland, C., (1978) "Marginal Effect of PRT Changes", Petroleum Economist, vol. 18, pp.501-503.

Robinson, C., Morgan, J., (1978) "North Sea Oil in the Future”, Macmillan Press Ltd. 
Rowland, C., Hann, D., (1987) "The Economics of North Sea Oil Taxation", Macmillan Press.

Ruairidh, S. (2003) "The UK North Sea: 2003 a Year of Transition?" Simmons \& Company International, Energy Industry Research, February 7.

Solana, J., (2006) "Towards an EU External Energy Policy" Speech given at at the EU Energy Conference, Brussels, 20 November 2006

Sassoon, J. (2003) “UKCS Exploration Consultation”, HM Treasury Exploration Steering Group.

Sem, T., Ellerman, D. (1997) "North Sea Reserve Appreciation, Production and Depletion", Massachusetts Institute of Technology.

The Norwegian Petroleum Directorate (2007) “The Norwegian Petroleum Sector - Facts 2007”, http://www.npd.no

The Norwegian Ministry of Foreign Affairs (2007) "The Norwegian Government's High North Strategy".

Tjersland, R. (2007) "Norway's role in contribution to EU Security of Supply”, Brussels, March 28.

Oil \& Gas UK (2006) "Energy Now and for the Future", UK Offshore Operators Association Economic Report 2006

Oil \& Gas UK (2006) “Activity Survey 2006”, UK Offshore Operators Association.

Watkins, C. (2000) "Characteristics of North Sea Oil Reserve Appreciation”, Massachusetts Institute of Technology, Cambridge, USA.

Webb, M. (2007) "Oil and Gas UK: The continued importance of indigenous oil and gas Production", UKOOA dinner debate, March $28^{\text {th }}$.

Wurtzen, A. (2007) “EU Security of Supply - A Danish Perspective”, Brussels Dinner Debate, March 28th.

Westwood, H. (2007) “UKCS - Looking Ahead”, Petroleum Review, vol. 61, no. 722, pp. 46-47. 

Note:

This paper may not be quoted or reproduced without permission

Surrey Energy Economics Centre (SEEC) Department of Economics University of Surrey

Guildford Surrey GU2 7XH 
SuRReY

ENERGY $_{\text {Net }}$

Economics

Discussion paper

$\mathbf{S}_{\text {ERIES }}$

\title{
For further information about SEEC please go to:
}

\author{
www.seec.surrey.ac.uk
}

